\title{
Vibrational spectroscopy and ab initio MO study of the molecular structure and vibrational spectra of $\alpha$ - and $\gamma$-pyrones
}

\author{
Rui Fausto ${ }^{1, *}$, Graciete Quinteiro, Susana Breda \\ Departamento de Química, Universidade de Coimbra, P-3049 Coimbra, Portugal
}

Received 21 March 2001; accepted 2 May 2001

\begin{abstract}
The molecular structures and vibrational spectra of the monomeric forms of $\alpha$ - and $\gamma$-pyrones were investigated by ab initio MO calculations, undertaken at the HF/6-31 $\mathrm{G}^{*}$ level of theory, and vibrational spectroscopy, including matrix-isolation FTIR spectroscopy. A complete assignment of the vibrational spectra of the studied compounds isolated in an argon matrix, at $8 \mathrm{~K}$, or in the condensed phases, at room temperature, is presented and the vibrational data correlated with some important structural parameters. It is shown that the intermolecular interactions in the room temperature condensed phases do not affect the structure and vibrational properties of the studied molecules strongly, though the vibrational results clearly reveal minor changes induced in the carbonyl groups that indirectly affect the electron distribution in the whole pyrone rings, leading to an increase in their $\pi$ electron delocalization. For the isolated monomers, both structural and vibrational results point to a relatively weak $\pi$-electron delocalization in both $\alpha$ - and $\gamma$-pyrone moieties. (c) 2001 Elsevier Science B.V. All rights reserved.
\end{abstract}

Keywords: $\alpha$-Pyrone; $\gamma$-Pyrone; Molecular structure; Matrix-isolation; FTIR and Raman spectra; 6-31G* MO ab initio calculations

\section{Introduction}

Important naturally occurring compounds and synthetic pesticides, such as the coumarins, psoralens and chromones, that are known to be potent photosensitizers, possess pyrone moieties as their fundamental structural nucleus [1,2]. Pyrones (Fig. 1) are also very useful reagents in organic synthesis, as in the Diels Alder reaction and used as prototype molecules to study photochemical ring formation and ring breaking reactions. However, the available structural and spectroscopic information on these compounds is relatively scarce, even though a large number of

\footnotetext{
* Corresponding author. Tel.: +351-239-852-080; fax: +351239-827-703.

E-mail address: rfausto@ci.uc.pt (R. Fausto).

${ }^{1}$ URL: http:/www.qui.uc.pt/ rfausto/homepage.
}

publications related to the more complex photosensitizers mentioned above can be found in the literature [3].

The crystal structure of $\alpha$-pyrone at $150 \mathrm{~K}$ (orthorhombic, Pna $2_{1}$ ) determined by Blake and coworkers [4], was found to consist of discrete molecules packed in a herringbone fashion in the unit cell. In turn, the molecular structure of $\gamma$-pyrone was obtained in the gaseous phase by microwave spectroscopy $\left(\mathrm{r}_{\mathrm{s}}\right.$ structure) [5] and later on studied both by semiempirical and ab initio Hartree-Fock level calculations [6-10], the latter undertaken with the relatively modest 3-21G and 4-21G split valence basis sets. The infrared and Raman spectra (at $T=310$ and $328 \mathrm{~K}$, respectively) of melted $\gamma$-pyrone and also the infrared spectrum of the gas was presented in Ref. [10] and interpreted on the basis of the 4-21G ab initio calculations. More recently, we have undertaken a photophysical 

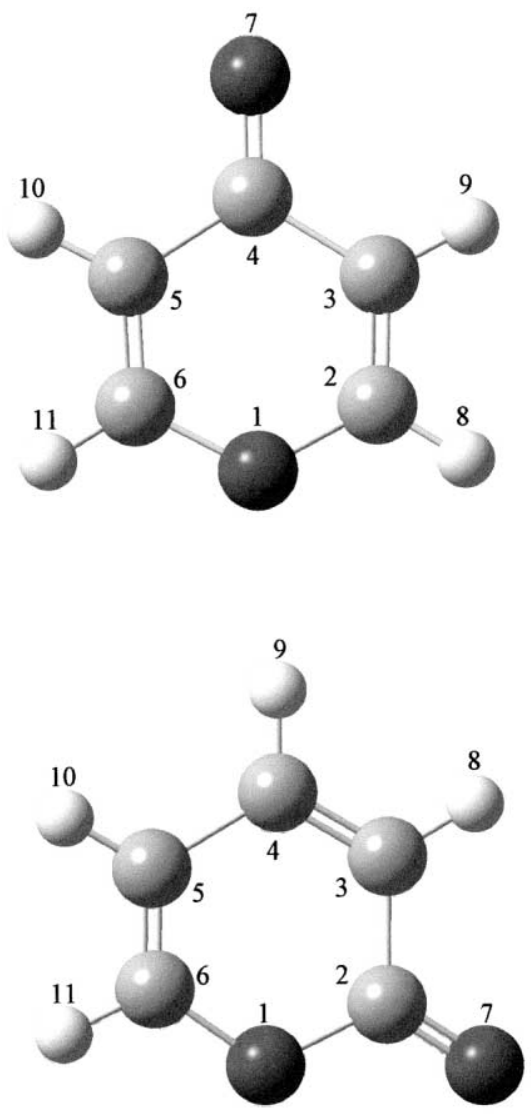

Fig. 1. Schematic drawing of $\alpha$ - and $\gamma$-pyrone with atom numbering.

characterization of ground and lowest excited states of $\alpha$ - and $\gamma$-pyrones and their substituted 4-hydroxy and 4-methoxy derivatives, by UV-absorption, fluorescence and phosphorescence spectroscopies [11]. In that study, we have also established several correlations between the structure of the electronic ground states of the various pyrones investigated, and the available condensed-phase vibrational data [12]. Based on these correlations, we were able to further support the idea, previously extracted from structural studies [4-10], that no extensive $\pi$-system delocalization occurs in both $\alpha$ - and $\gamma$-pyrone moieties [11]. However, since intermolecular interactions in the condensed phases might be playing an important role in determining the relevant vibrational data, it appeared to be important for our further understanding on these systems, to obtain detailed spectro- scopic data for the isolated monomeric species. With this in view, in the present study, the monomers of $\alpha$ and $\gamma$-pyrones in argon matrices were investigated by matrix-isolation infrared spectroscopy, at $8 \mathrm{~K}$. Theoretical results obtained using ab initio molecular orbital calculations, undertaken at the HF/6-31G level of theory, and normal coordinate analysis were used to help interpretation of the observed spectroscopic data.

\section{Experimental and computational details}

Alpha and $\gamma$-pyrones were commercially obtained spectroscopic grade and purified by standard methods before use. Argon $99.99990 \%$ purity was supplied by Air Liquids.

The matrices were prepared either by pre-mixing Ar and the solute before deposition $(T=298 \mathrm{~K})$ or by codeposition, using a Knudsen cell, directly connected to the cryostat by a regulable SS-4BMRG micrometer valve (Nupro), as substance container prior to deposition. The matrices were deposited on a $\mathrm{KBr}$ window, cooled using an APD Cryogenics Displex DE202 closed-cycle Helium refrigerator connected to a high efficiency vacuum system whose main component is an Alcatel PTR5001 turbomolecular pump. The deposition temperature, measured at the window using a Scientific Instruments digital temperature controller (model 9650), was $8 \mathrm{~K}$. The matrix:solute ratios were ca. 1000 and the rates of the matrix gas flow ca. $5.0 \times 10^{-3} \mathrm{~mol} \mathrm{~h}^{-1}$.

Infrared spectra were obtained using a Mattson RA60 Infinity Series Fourier Transform spectrometer, equipped with a germanium/ $\mathrm{KBr}$ beam splitter and a deuterated triglycine sulphide (DTGS) detector fitted with $\mathrm{KBr}$ windows, using a spectral resolution of $1 \mathrm{~cm}^{-1}$.

Raman spectra were obtained using a SPEX 1403 double monochromator spectrometer (focal distance $0.85 \mathrm{~m}$, aperture $f / 7.8$ ), equipped with holographic gratings with 1800 grooves $\mathrm{mm}^{-1}$ (ref. 1800-1SHD). The $514.5 \mathrm{~nm}$ argon laser (Spectra-Physics, model 164-05) line, adjusted to provide $220 \mathrm{~mW}$ power at the sample, was used as excitation radiation. Detection was effected using a thermoelectrically cooled Hamamatsu R928 photomultiplier. Spectra were recorded using increments of $1 \mathrm{~cm}^{-1}$ and integration times of $1 \mathrm{~s}$. 
Table 1

Calculated $\left(\mathrm{HF} / 6-31 \mathrm{G}^{*}\right)$ and experimental molecular geometries and energies for $\alpha$-and $\gamma$-pyrone (see Fig. 1 for atom numbering; both molecules were predicted to be planar: $\gamma$-pyrone $\left(C_{2 v}\right) ; \alpha$-pyrone $\left(C_{s}\right)$ )

\begin{tabular}{|c|c|c|c|c|c|}
\hline \multicolumn{3}{|l|}{$\gamma$-Pyrone } & \multicolumn{3}{|l|}{$\alpha$-Pyrone } \\
\hline Parameter & Calculated & Experimental [5] & Parameter & Calculated & Experimental [4] \\
\hline \multicolumn{6}{|c|}{ Bond length (pm) } \\
\hline \multirow[t]{2}{*}{$\mathrm{O}-\mathrm{C}$} & 134.2 & 135.8 & $\mathrm{O}-\mathrm{C} 2$ & 136.3 & 138.4 \\
\hline & & & $\mathrm{O}-\mathrm{C} 6$ & 133.9 & 135.8 \\
\hline $\mathrm{C}=\mathrm{O}$ & 120.0 & 122.6 & $\mathrm{C}=\mathrm{O}$ & 118.4 & 120.7 \\
\hline \multirow[t]{2}{*}{$\mathrm{C}=\mathrm{C}$} & 132.7 & 134.4 & $\mathrm{C} 3=\mathrm{C} 4$ & 133.5 & 133.9 \\
\hline & & & $\mathrm{C} 5=\mathrm{C} 6$ & 132.7 & 133.8 \\
\hline \multirow[t]{2}{*}{$\mathrm{C}-\mathrm{C}$} & 147.0 & 146.3 & $\mathrm{C} 2-\mathrm{C} 3$ & 146.1 & 143.9 \\
\hline & & & $\mathrm{C} 4-\mathrm{C} 5$ & 144.7 & 142.4 \\
\hline $\mathrm{C} 2-\mathrm{H}$ & 107.1 & 108.2 & $\mathrm{C} 3-\mathrm{H}$ & 107.2 & - \\
\hline \multirow[t]{3}{*}{$\mathrm{C} 3-\mathrm{H}$} & 107.2 & 107.9 & $\mathrm{C} 4-\mathrm{H}$ & 107.5 & - \\
\hline & & & $\mathrm{C} 5-\mathrm{H}$ & 107.2 & - \\
\hline & & & C6-H & 107.1 & - \\
\hline \multicolumn{6}{|c|}{ Bond angle $\left({ }^{\circ}\right)$} \\
\hline \multirow[t]{2}{*}{$\mathrm{O}-\mathrm{C}=\mathrm{C}$} & 123.9 & 123.9 & $\mathrm{O}-\mathrm{C} 6=\mathrm{C} 5$ & 123.1 & 122.6 \\
\hline & & & $\mathrm{O}-\mathrm{C} 2-\mathrm{C} 3$ & 115.4 & 115.9 \\
\hline $\mathrm{C}-\mathrm{C}=\mathrm{C}$ & 120.5 & 120.9 & $\mathrm{C} 4-\mathrm{C} 5=\mathrm{C} 6$ & 117.4 & 117.9 \\
\hline \multirow[t]{2}{*}{$\mathrm{C}-\mathrm{C}-\mathrm{C}$} & 112.8 & 113.1 & $\mathrm{C} 3=\mathrm{C} 4-\mathrm{C} 5$ & 120.2 & 120.8 \\
\hline & & & $\mathrm{C} 2-\mathrm{C} 3=\mathrm{C} 4$ & 120.7 & 121.0 \\
\hline \multirow[t]{2}{*}{$\mathrm{C}-\mathrm{C}=\mathrm{O}$} & 123.6 & 123.5 & $\mathrm{C}-\mathrm{C}=\mathrm{O}$ & 126.0 & 127.8 \\
\hline & & & $\mathrm{O}=\mathrm{C}-\mathrm{O}$ & 118.6 & 116.3 \\
\hline $\mathrm{C}-\mathrm{O}-\mathrm{C}$ & 118.7 & 117.3 & $\mathrm{C}-\mathrm{O}-\mathrm{C}$ & 123.1 & 122.1 \\
\hline $\mathrm{O}-\mathrm{C}-\mathrm{H}$ & 111.3 & 110.9 & $\mathrm{O}-\mathrm{C}-\mathrm{H}$ & 111.7 & - \\
\hline \multirow[t]{3}{*}{$\mathrm{C}-\mathrm{C}-\mathrm{H}$} & 119.0 & 119.1 & $\mathrm{C} 2-\mathrm{C} 3-\mathrm{H}$ & 116.0 & - \\
\hline & & & $\mathrm{C} 3=\mathrm{C} 4-\mathrm{H}$ & 120.4 & - \\
\hline & & & $\mathrm{C} 4-\mathrm{C} 5-\mathrm{H}$ & 121.8 & - \\
\hline
\end{tabular}

The ab initio molecular orbital calculations were performed using the $6-31 \mathrm{G}^{*}$ basis set [13] with the GAUSSIAN 94 program package [14] running on a DEC ALPHA 7000 computer. Molecular geometries were fully optimized by the force gradient method using Berny's algorithm [15] and the standard convergence criteria for geometry optimization. The force constants (symmetry internal coordinates) to be used in the normal coordinate analysis were obtained from the ab initio cartesian harmonic force constants using the program TRANSFORMER (version 2.0) [16]. This program was also used to prepare the input data for the normal coordinate analysis programs used in this study (BUILD-G and VIBRAT [17]). A single scaling factor (0.89) was applied to the calculated frequencies. While very simple, this scaling procedure preserves the potential energy distributions (PEDs) as they emerge from the ab initio calculations, thus having an important advantage over the more elabo- rate force field scaling procedures which use more than one scale factor, which usually give rise to important PEDs distortions from the ab initio calculated values.

\section{Results and discussion}

Table 1 shows the HF/6-31G* calculated equilibrium molecular geometries for the studied compounds. The previously reported structural data [4,5] are also presented in this table. Despite the fact that the different sets of data are not directly comparable, it can be noticed that, for both molecules, the calculated values show a good general agreement with the experimental values, and improve over the previously reported theoretical data [6-10]. This result is in agreement with the existence of relatively weak intermolecular interactions between the 


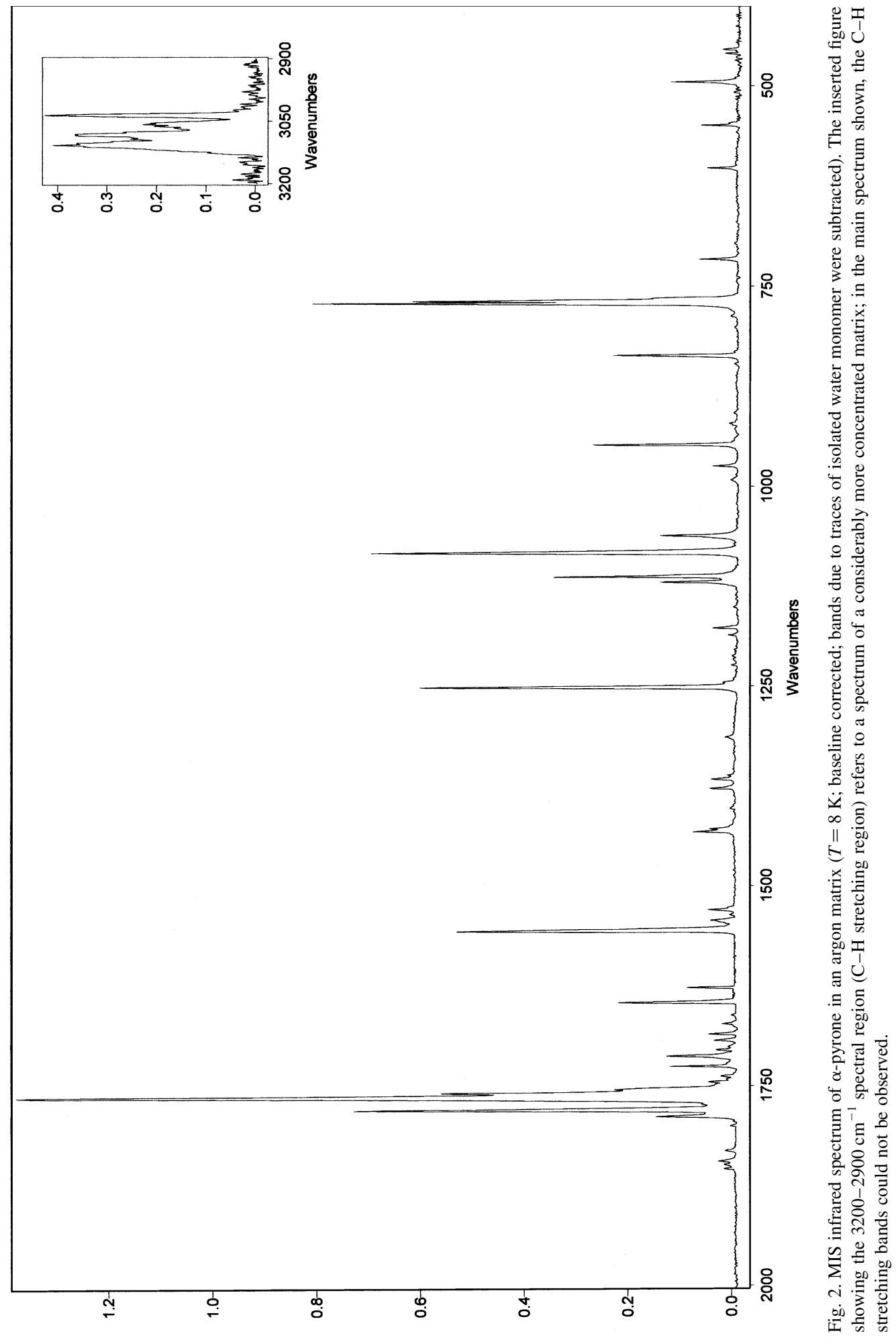




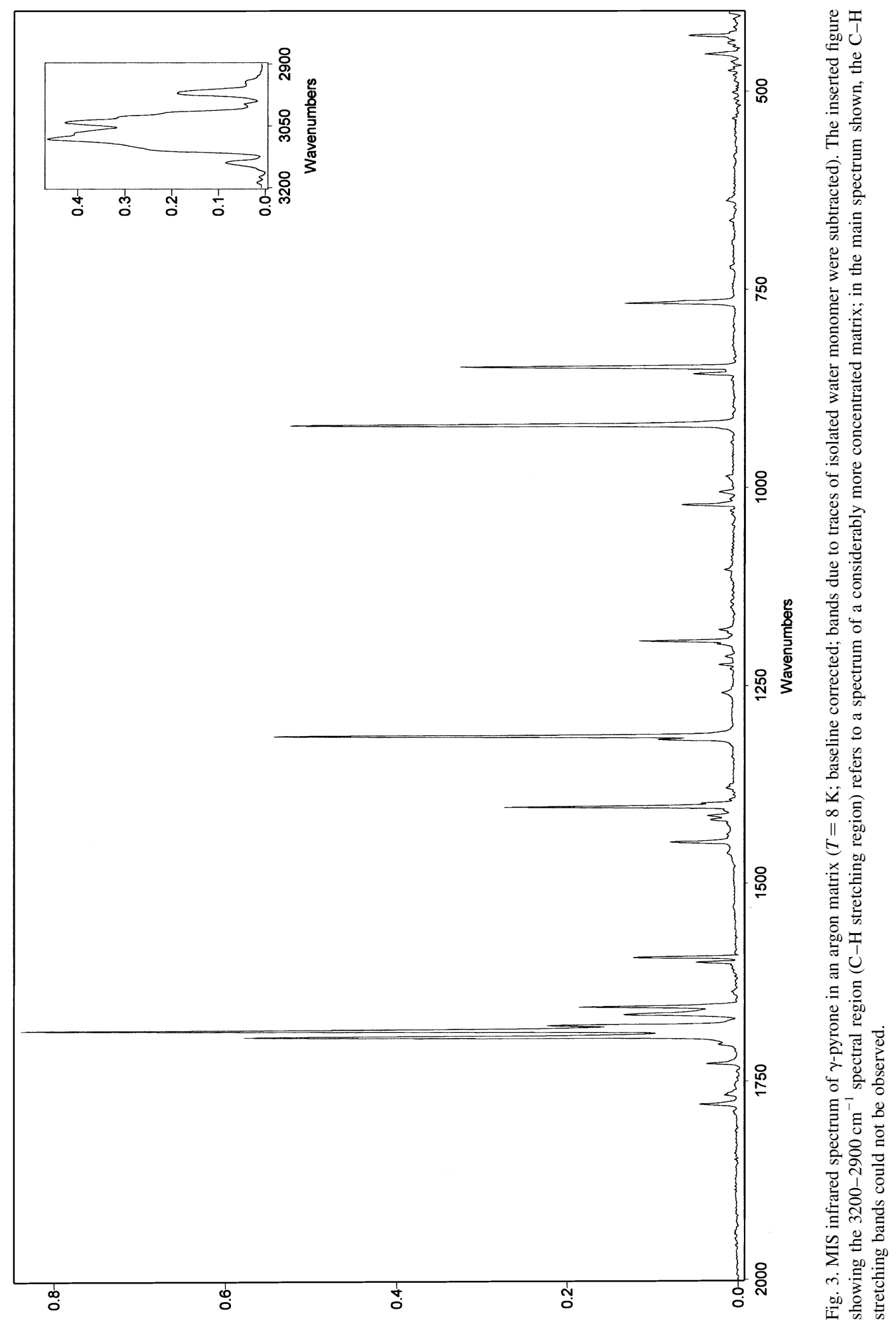




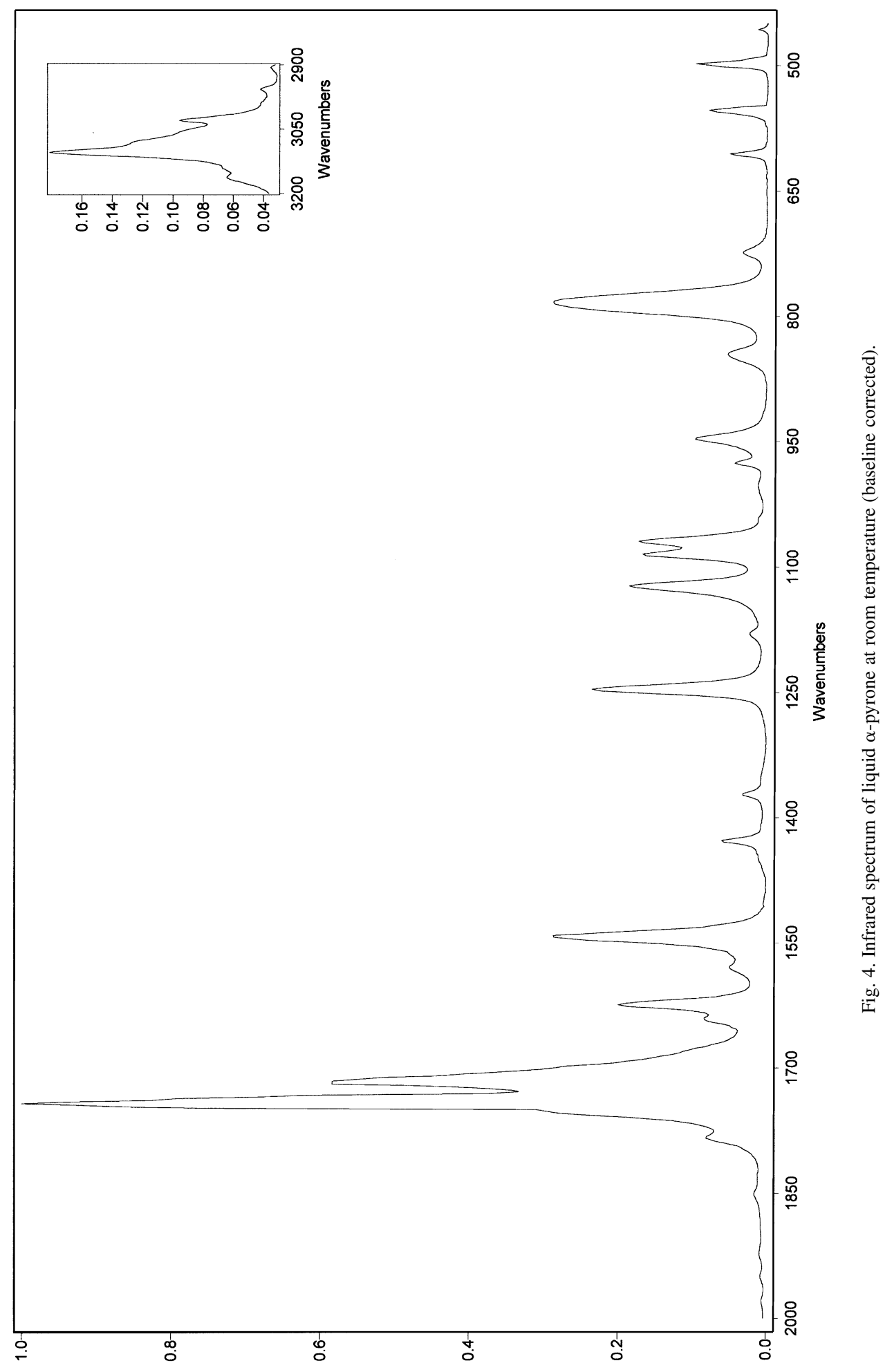




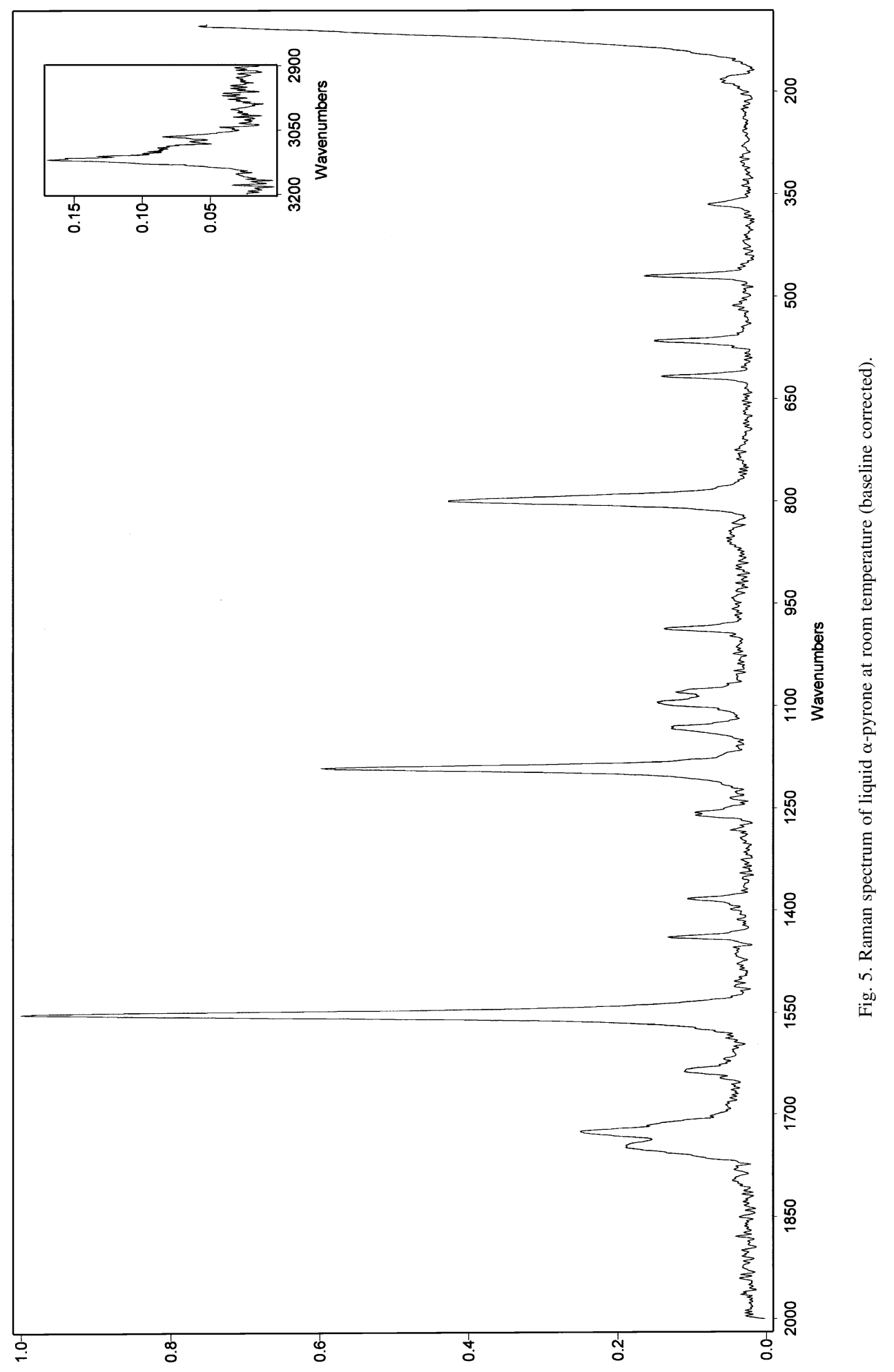


Table 2

Symmetry coordinates for $\alpha$-pyrone (see Fig. 1 for atom numbering. $\nu$, stretching; $\delta$, in-plane bending; $\gamma$, out-of-plane-bending; $\tau$, torsion; normalization factors $(N)$ not indicated; they are obtained as $N=1 / \sqrt{\sum} C_{i}^{2}$, where $C_{i}$ is the coefficient of combination associated with the internal coordinate $i$ )

\begin{tabular}{ll}
\hline Coordinate \\
\hline$A^{\prime}$ symmetry \\
$\mathrm{S}_{1} \quad \nu(\mathrm{O}-\mathrm{C} 2)$ \\
$\mathrm{S}_{2} \quad \nu(\mathrm{O}-\mathrm{C} 6)$ \\
$\mathrm{S}_{3} \quad \nu(\mathrm{C}=\mathrm{O})$ \\
$\mathrm{S}_{4} \quad \nu(\mathrm{C} 2-\mathrm{C} 3)$ \\
$\mathrm{S}_{5} \quad \nu(\mathrm{C} 5=\mathrm{C} 6)$ \\
$\mathrm{S}_{6} \quad \nu(\mathrm{C} 3=\mathrm{C} 4)$ \\
$\mathrm{S}_{7} \quad \nu(\mathrm{C} 4-\mathrm{C} 5)$ \\
$\mathrm{S}_{8} \quad \nu(\mathrm{C} 3-\mathrm{H})$ \\
$\mathrm{S}_{9} \quad \nu(\mathrm{C} 4-\mathrm{H})$ \\
$\mathrm{S}_{10}$ & $\nu(\mathrm{C} 5-\mathrm{H})$ \\
$\mathrm{S}_{11}$ & $\nu(\mathrm{C} 6-\mathrm{H})$ \\
$\mathrm{S}_{12}$ & $\delta(\mathrm{C} 4=\mathrm{C} 3-\mathrm{C} 2)-\delta(\mathrm{C} 3=\mathrm{C} 4-\mathrm{C} 5)+\delta(\mathrm{C} 6=\mathrm{C} 5-$ \\
& $\mathrm{C} 4)-\delta(\mathrm{C} 5=\mathrm{C}-\mathrm{O})$ \\
$\mathrm{S}_{13}$ & $\delta(\mathrm{C}-\mathrm{C}=\mathrm{O})-\delta(\mathrm{O}-\mathrm{C}=\mathrm{O})$ \\
$\mathrm{S}_{14}$ & $\delta(\mathrm{C} 4=\mathrm{C} 3-\mathrm{H})-\delta(\mathrm{C} 2-\mathrm{C} 3-\mathrm{H})$ \\
$\mathrm{S}_{15}$ & $\delta(\mathrm{C} 5-\mathrm{C} 4-\mathrm{H})-\delta(\mathrm{C} 3=\mathrm{C} 4-\mathrm{H})$ \\
$\mathrm{S}_{16}$ & $\delta(\mathrm{C} 6=\mathrm{C} 5-\mathrm{H})-\delta(\mathrm{C} 4-\mathrm{C} 5-\mathrm{H})$ \\
$\mathrm{S}_{17}$ & $\delta(\mathrm{O}-\mathrm{C} 6-\mathrm{H})-\delta(\mathrm{C} 5=\mathrm{C} 6-\mathrm{H})$ \\
$\mathrm{S}_{18}$ & $5 \delta(\mathrm{C}-\mathrm{O}-\mathrm{C})-\delta(\mathrm{O}-\mathrm{C} 2-\mathrm{C} 3)-\delta(\mathrm{C} 2-\mathrm{C} 3=\mathrm{C} 4)-\delta \mathrm{C} 3=\mathrm{C} 4-$ \\
& $\mathrm{C} 5)-\delta(\mathrm{C} 4-\mathrm{C} 5=\mathrm{C} 6)-\delta(\mathrm{C} 5=6-\mathrm{O})$ \\
$\mathrm{S}_{19}$ & $4 \delta(\mathrm{O}-\mathrm{C} 2-\mathrm{C} 3)-\delta(\mathrm{C} 5=\mathrm{C}-\mathrm{O})-\delta(\mathrm{C} 4=\mathrm{C} 3-\mathrm{C} 2)-\delta(\mathrm{C} 4-$ \\
& $\mathrm{C} 5=\mathrm{C} 6)-\delta(\mathrm{C} 5-\mathrm{C} 4=\mathrm{C} 3)$ \\
$A^{\prime \prime}$ & $\mathrm{symmetry}$ \\
$\mathrm{S}_{20}$ & $\gamma(\mathrm{C}=\mathrm{O})$ \\
$\mathrm{S}_{21}$ & $\gamma(\mathrm{C} 3-\mathrm{H})$ \\
$\mathrm{S}_{22}$ & $\gamma(\mathrm{C} 4-\mathrm{H})$ \\
$\mathrm{S}_{23}$ & $\gamma(\mathrm{C} 5-\mathrm{H})$ \\
$\mathrm{S}_{24}$ & $\gamma(\mathrm{C} 6-\mathrm{H})$ \\
$\mathrm{S}_{25}$ & $\tau(\mathrm{C} 2-\mathrm{O})$ \\
$\mathrm{S}_{26}$ & $\tau(\mathrm{C} 3-\mathrm{C} 2)+\tau(\mathrm{C} 4-\mathrm{C} 5)$ \\
$\mathrm{S}_{27}$ & $\tau(\mathrm{C} 6-\mathrm{O})$ \\
&
\end{tabular}

monomeric species in the solid state, a result that is in consonance with the reported X-ray structure of $\alpha$ pyrone [4].

A detailed comparative analysis of the geometries of $\alpha$ - and $\gamma$-pyrones was already made elsewhere [11] and will not be repeated here. The most important conclusion that can be extracted from Table 1 is that no extended conjugation involving the carbon-carbon bonds occurs in the studied compounds, since the $\mathrm{C}-$ $\mathrm{C}$ and $\mathrm{C}=\mathrm{C}$ bond lengths are significantly longer and shorter, respectively, than the carbon-carbon bond lengths in a typical aromatic six-membered ring (ca.
$139 \mathrm{pm})$. Indeed, the $\mathrm{C}-\mathrm{C}$ bond lengths in the pyrones $(144.7-147.0 \mathrm{pm})$ were found to be similar to the central bond in butadiene (146.3 pm [18]), while the $\mathrm{C}=\mathrm{C}$ bond lengths $(132.7-133.5 \mathrm{pm})$ do not differ very much from the $\mathrm{C}=\mathrm{C}$ bond length in ethylene (133.7 pm [19]). Other important conclusions are that in $\alpha$-pyrone, a considerably strong repulsive interaction between the lone pairs of electron of the oxygen atoms is operating and that no significant $\pi$ electron delocalization from $\mathrm{O} 1$ to the carbonyl group occurs. These conclusions are suggested by the considerably large $\mathrm{O}-\mathrm{C} 2$ bond length and shorter $\mathrm{C}=\mathrm{O}$ bond in $\alpha$-pyrone (when compared either with that of the $\mathrm{O}-\mathrm{C} 6$ bond in the same molecule or with those associated with the equivalent $\mathrm{O}-\mathrm{C}$ bonds in $\gamma$ pyrone).

As it will be shown below, the vibrational spectra of the studied compounds clearly reflect the above structural features.

The infrared spectra of $\alpha$ - and $\gamma$-pyrones isolated in an argon matrix are shown in Figs. 2 and 3. The room temperature spectra (infrared and Raman) are presented in Figs. 4-6. The first molecule belongs to the $C_{s}$ point group and its 27 fundamental vibrations spawn the irreducible representations $19 A^{\prime}+$ $8 A^{\prime \prime}$, all being active both in infrared and in Raman. $\gamma$-pyrone shows $C_{2 v}$ symmetry and its normal coordinates spawn the irreducible representations $10 A_{1}+$ $3 A_{2}+5 B_{1}+9 B_{2}$, with the three $A_{2}$ vibrations being inactive in infrared. Tables 2 and 3 present the definition of the symmetry coordinates used in the vibrational calculations. The calculated spectra, vibrational assignments and potential energy distributions (PEDs) are shown in Tables 4-7.

\section{1. $\alpha$-Pyrone}

The infrared spectra of $\alpha$-pyrone in argon (Fig. 2) is dominated by the intense bands (or groups of bands due to matrix splitting effects or Fermi resonance interactions $)$ due to the $\mathrm{CO}(\nu \mathrm{C}=\mathrm{O}, \nu \mathrm{C} 6-\mathrm{O}$ and $\nu \mathrm{C} 2-\mathrm{O})$ and $\mathrm{C}=\mathrm{C}(\nu \mathrm{C} 3=\mathrm{C} 4$ and $\nu \mathrm{C} 5=\mathrm{C} 6)$ stretching modes as well as to the $\delta \mathrm{C} 5-\mathrm{H}$ and $\gamma \mathrm{C} 5-\mathrm{H}$ bending modes. These bands are also the most intense features in the infrared spectrum of the pure liquid (Fig. 4). The $\nu \mathrm{C}=\mathrm{O}$ stretching mode is predicted by the calculations to give rise to an extremely intensive infrared band, and, accordingly, this is by far the most intense 
Table 3

Symmetry coordinates for $\gamma$-pyrone (see Fig. 1 for atom numbering. $\nu$, stretching; $\delta$, in-plane bending; $\gamma$, out-of-plane-bending; $\tau$, torsion; normalization factors $(N)$ not indicated; they are obtained as $N=1 / \sqrt{\sum} C_{i}^{2}$, where $C_{i}$ is the coefficient of combination associated with the internal coordinate $i$ )

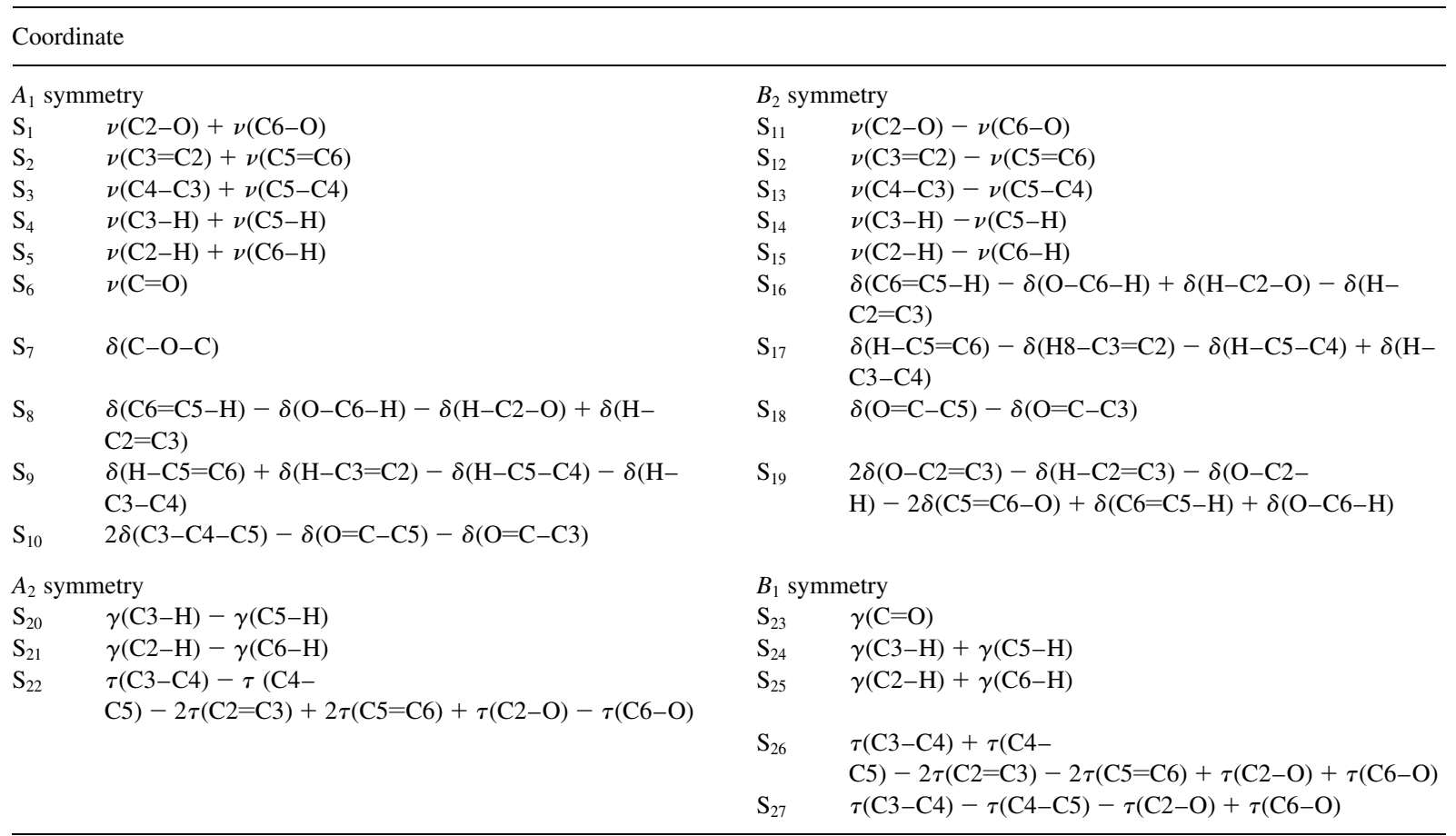

feature in the observed spectra. The observed splitting in the spectrum of the pure liquid is due to a Fermi resonance interaction involving the combination tone $\gamma \mathrm{C} 6-\mathrm{H}+\gamma \mathrm{C} 5-\mathrm{H}$, while the complex structure observed in the carbonyl stretching region in the spectrum of the isolated molecule in argon results from this effect and matrix site splitting. It is well known that the intense infrared bands due to vibrations mainly localized in polar groups are those that more frequently exhibit splitting due to non-equivalence of matrix trapping sites [20-22], as it is observed in the present case.

The relative position of the $\nu \mathrm{C} 6-\mathrm{O}$ and $\nu \mathrm{C} 2-\mathrm{O}$ bands follows the expected pattern: the repulsive interaction between the lone electron pairs of the oxygen atoms makes the $\mathrm{C} 2-\mathrm{O}$ bond considerably weaker than the $\mathrm{C} 6-\mathrm{O}$ bond, leading both to the above mentioned increase in the $\mathrm{C}-\mathrm{O}$ bond length and to the observed decrease in the stretching frequency associated with the $\mathrm{C} 2-\mathrm{O}$ bond. The observed shift to lower frequencies is of ca.
$130 \mathrm{~cm}^{-1}$, which agrees very well with the predicted value $\left(132 \mathrm{~cm}^{-1}\right.$; see Table 4$)$. It is also interesting to note that $\nu \mathrm{C} 6-\mathrm{O}$ slightly decreases and $\nu \mathrm{C} 2-\mathrm{O}$ slightly increases in going from the isolated molecule situation to the pure liquid (see Table 6), indicating that the intermolecular interactions in the condensed phase lead to charge migration from the $\mathrm{C} 6-\mathrm{O}$ bond towards the $\mathrm{C} 2-\mathrm{O}$ bond. Indeed, this is in also in agreement with the observed decrease in the $\nu \mathrm{C}=\mathrm{O}$ frequency, which reveals that in the pure liquid the carbonyl bond is more polarized, i.e. the canonical form $\mathrm{C} 6-\mathrm{O} 1=\mathrm{C}^{+}-\mathrm{O}^{-}$, becomes relatively more important than in the isolated molecule situation.

The relatively large infrared intensity of the $\delta \mathrm{C} 5-$ $\mathrm{H}$ and $\gamma \mathrm{C} 5-\mathrm{H}$ bands when compared with those ascribed to the analogous vibrations involving the remaining $\mathrm{C}-\mathrm{H}$ fragments can be easily explained by looking at the potential energy distribution associated with these two vibrations. In fact, $\delta \mathrm{C} 5-\mathrm{H}$ strongly mixes with the $\nu \mathrm{C} 6-\mathrm{O}$ coordinate, while $\gamma \mathrm{C} 5-\mathrm{H}$ is coupled with the $\gamma$-ring-1 coordinate, 
Table 4

Calculated and observed vibrational frequencies, intensities and potential energy distributions (PED) for $\alpha$-pyrone monomer (frequencies in $\mathrm{cm}^{-1} . \nu$, stretching, $\delta$, in-plane bending; $\gamma$, out-of-plane bending, $\tau$, torsion; FR, Fermi Resonance; see Fig. 1 for atom numbering; calculated infrared intensities $\left(I^{\mathrm{r}}\right)$ in $\mathrm{km} \mathrm{mol}^{-1}$; calculated Raman activities $\left(I^{\mathrm{R}}\right)$ in $\AA^{4}$ Dalton ${ }^{-1}$; experimental intensities are peak intensities, normalized to the most intense band (only those bands with intensity larger than 0.5 are reported); assignment of overtones and combination bands should be considered as tentative)

\begin{tabular}{|c|c|c|c|c|c|c|c|}
\hline \multirow[t]{2}{*}{ Approximate description } & \multirow[t]{2}{*}{ Symmetry } & \multicolumn{3}{|c|}{ Calculated (HF/6-31G*) } & \multicolumn{2}{|c|}{$\begin{array}{l}\text { Observed (infrared, Ar matrix, } \\
T=8 \mathrm{~K} \text { ) }\end{array}$} & \multirow[t]{2}{*}{$\mathrm{PED}^{\mathrm{a}}$} \\
\hline & & $\nu$ & $I^{\mathrm{ir}}$ & $I^{\mathrm{R}}$ & $\nu$ & $I$ & \\
\hline $2 \times \nu(\mathrm{C}=\mathrm{O})$ & $A^{\prime}$ & & & & 3515 & 6.3 & \\
\hline$\nu(\mathrm{C} 6-\mathrm{H})$ & $A^{\prime}$ & 3066 & 8.7 & 142.9 & 3108 & & $S_{11}(83)+S_{10}(16)$ \\
\hline$\nu(\mathrm{C} 3-\mathrm{H})$ & $A^{\prime}$ & 3048 & 1.6 & 84.4 & 3083 & & $\mathrm{~S}_{8}(91)$ \\
\hline$\nu(\mathrm{C} 5-\mathrm{H})$ & $A^{\prime}$ & 3041 & 1.1 & 72.0 & 3057 & & $S_{10}(80)+S_{11}(15)$ \\
\hline$\nu(\mathrm{C} 4-\mathrm{H})$ & $A^{\prime}$ & 3010 & 10.8 & 79.5 & 3036 & & $\mathrm{~S}_{9}(92)$ \\
\hline$\nu(\mathrm{C} 6-\mathrm{O})+\delta$ ring 2 & $A^{\prime}$ & & & & 1854 & 1.6 & \\
\hline$\delta(\mathrm{C} 5-\mathrm{H})+\nu(\mathrm{C} 2-\mathrm{C} 3)$ & $A^{\prime}$ & & & & 1849 & 1.6 & \\
\hline $2 \times \delta \operatorname{ring} 1$ & $A^{\prime}$ & & & & 1845 & 2.4 & \\
\hline$\gamma(\mathrm{C} 4-\mathrm{H})+\gamma(\mathrm{C} 5-\mathrm{H})$ & $A^{\prime}$ & & & & 1832 & 1.5 & \\
\hline$\delta(\mathrm{C} 6-\mathrm{H})+\delta(\mathrm{C}-\mathrm{C}-\mathrm{O})$ & $A^{\prime}$ & & & & 1800 & 0.7 & \\
\hline \multirow[t]{2}{*}{$\begin{array}{l}\nu(\mathrm{C}=\mathrm{O}) \text { FR with }(\gamma \mathrm{C} 6- \\
\mathrm{H}+\gamma \mathrm{C} 5-\mathrm{H})\end{array}$} & $A^{\prime}$ & 1805 & 765.4 & 48.0 & $1788,1787,1781$ & $11.0,6.8,52.4$ & $\mathrm{~S}_{3}(93)$ \\
\hline & & & & & $1764,1759,1755$ & $100.0,40.6,16.7$ & \\
\hline$\nu(\mathrm{C} 6-\mathrm{O})+\gamma(\mathrm{C}=\mathrm{O})$ & $A^{\prime \prime}$ & & & & 1745 & 3.8 & \\
\hline$\nu(\mathrm{C} 2-\mathrm{C} 3)+\nu(\mathrm{C} 4-\mathrm{C} 5)$ & $A^{\prime}$ & & & & 1738 & 2.0 & \\
\hline$\nu(\mathrm{C} 2-\mathrm{O})+\delta$ ring 2 & $A^{\prime}$ & & & & 1725 & 9.0 & \\
\hline$\nu(\mathrm{C} 2-\mathrm{C} 3)+\delta$ ring 1 & $A^{\prime}$ & & & & 1713 & 9.5 & \\
\hline$\nu(\mathrm{C} 6-\mathrm{O})+\delta(\mathrm{C}=\mathrm{O})$ & $A^{\prime}$ & & & & 1705,1702 & $2.7,1.1$ & \\
\hline $2 \times \gamma(\mathrm{C} 3-\mathrm{H})$ & $A^{\prime}$ & & & & 1693,1672 & $2.9,1.9$ & \\
\hline$\delta(\mathrm{C} 5-\mathrm{H})+\delta \operatorname{ring} 2$ & $A^{\prime}$ & & & & 1685 & 3.7 & \\
\hline$\delta \operatorname{ring} 1+\gamma \operatorname{ring} 2$ & $A^{\prime \prime}$ & & & & 1662 & 0.6 & \\
\hline$\nu(\mathrm{C} 5=\mathrm{C} 6)$ & $A^{\prime}$ & 1659 & 51.7 & 4.5 & 1646,1627 & $16.1,6.7$ & $S_{5}(40)+S_{6}(33)+S_{15}(11)$ \\
\hline$\nu(\mathrm{C} 3=\mathrm{C} 4)$ & $A^{\prime}$ & 1565 & 112.3 & 111.9 & 1557 & 38.4 & $\mathrm{~S}_{6}(46)+\mathrm{S}_{5}(35)+\mathrm{S}_{7}(18)$ \\
\hline $2 \times \gamma(\mathrm{C} 5-\mathrm{H})$ & $A^{\prime}$ & & & & 1542,1536 & $3.5,1.0$ & \\
\hline $2 \times \nu(\mathrm{C} 2-\mathrm{C} 3)$ & $A^{\prime}$ & & & & 1530 & 3.8 & \\
\hline$\delta(\mathrm{C} 6-\mathrm{H})$ & $A^{\prime}$ & 1414 & 6.4 & 9.7 & 1432,1428 & $5.9,3.6$ & $\begin{array}{l}S_{17}(26)+S_{16}(24)+S_{14} \\
(20)+S_{7}(18)\end{array}$ \\
\hline$\delta(\mathrm{C} 4-\mathrm{H})$ & $A^{\prime}$ & 1363 & 8.1 & 5.4 & 1377,1366 & $3.6,3.4$ & $\begin{array}{l}\mathrm{S}_{15}(27)+\mathrm{S}_{14}(22)+\mathrm{S}_{16} \\
(17)+\mathrm{S}_{17}(13)\end{array}$ \\
\hline$\nu(\mathrm{C} 3-\mathrm{C} 2)+\delta \operatorname{ring} 2$ & $A^{\prime}$ & & & & 1362 & 1.2 & \\
\hline$\gamma$ ring $2+\delta$ ring 2 & $A^{\prime \prime}$ & & & & 1314 & 1.5 & \\
\hline$\nu(\mathrm{C} 6-\mathrm{O})$ & $A^{\prime}$ & 1242 & 84.4 & 10.5 & 1252,1245 & $43.4,1.9$ & $S_{2}(35)+S_{17}(35)+S_{16}(14)$ \\
\hline$\gamma(\mathrm{C} 5-\mathrm{H})+\delta(\mathrm{C}=\mathrm{O})$ & $A^{\prime \prime}$ & & & & 1224 & 0.6 & \\
\hline$\delta(\mathrm{C} 3-\mathrm{H})$ & $A^{\prime}$ & 1171 & 10.8 & 28.0 & 1186,1177 & $1.0,3.2$ & $\begin{array}{l}S_{14}(32)+S_{1}(27)+S_{4} \\
(20)+S_{13}(14)\end{array}$ \\
\hline$\delta$ ring $2+\delta(\mathrm{C}-\mathrm{C}-\mathrm{O})$ & $A^{\prime}$ & & & & 1151 & 0.5 & \\
\hline$\nu(\mathrm{C} 2-\mathrm{O})$ & $A^{\prime}$ & 1110 & 45.8 & 2.6 & 1119,1114 & $10.4,25.0$ & $S_{1}(23)+S_{15}(47)+S_{14}(18)$ \\
\hline$\delta(\mathrm{C} 5-\mathrm{H})$ & $A^{\prime}$ & 1079 & 46.6 & 7.8 & 1084 & 50.1 & $\mathrm{~S}_{16}(32)+\mathrm{S}_{2}(34)$ \\
\hline$\gamma(\mathrm{C} 4-\mathrm{H})$ & $A^{\prime \prime}$ & 1013 & 0.5 & 4.2 & 1064,1062 & $4.1,10.4$ & $\mathrm{~S}_{22}(83)$ \\
\hline$\gamma(\mathrm{C} 6-\mathrm{H})$ & $A^{\prime \prime}$ & 966 & $<0.1$ & 1.8 & 993 & 0.8 & $\mathrm{~S}_{24}(84)$ \\
\hline$\nu(\mathrm{C} 4-\mathrm{C} 5)$ & $A^{\prime}$ & 949 & 1.3 & 5.0 & 974 & 3.3 & $S_{7}(58)+S_{13}(20)+S_{12}(16)$ \\
\hline$\delta$ ring 1 & $A^{\prime}$ & 927 & 9.7 & 0.8 & 948 & 19.6 & $S_{12}(65)+S_{1}(17)+S_{7}(14)$ \\
\hline$\gamma(\mathrm{C} 3-\mathrm{H})$ & $A^{\prime \prime}$ & 840 & 28.4 & 2.8 & 836 & 16.8 & $S_{21}(61)+S_{22}(16)+S_{23}(15)$ \\
\hline$\gamma(\mathrm{C} 5-\mathrm{H})$ & $A^{\prime \prime}$ & 778 & 85.6 & 6.0 & 772,769 & $58.2,44.4$ & $\mathrm{~S}_{23}(64)+\mathrm{S}_{25}(10)$ \\
\hline$\nu(\mathrm{C} 2-\mathrm{C} 3)$ & $A^{\prime}$ & 777 & 24.3 & 12.5 & 765 & 11.6 & $S_{4}(32)+S_{1}(47)$ \\
\hline
\end{tabular}


Table 4 (continued)

\begin{tabular}{|c|c|c|c|c|c|c|c|}
\hline \multirow[t]{2}{*}{ Approximate description } & \multirow[t]{2}{*}{ Symmetry } & \multicolumn{3}{|c|}{ Calculated (HF/6-31G*) } & \multicolumn{2}{|c|}{$\begin{array}{l}\text { Observed (infrared, Ar matrix, } \\
T=8 \mathrm{~K} \text { ) }\end{array}$} & \multirow[t]{2}{*}{$\mathrm{PED}^{\mathrm{a}}$} \\
\hline & & $\nu$ & $I^{\mathrm{ir}}$ & $I^{\mathrm{R}}$ & $\nu$ & $I$ & \\
\hline$\gamma \operatorname{ring} 2$ & $A^{\prime \prime}$ & 721 & $<0.1$ & 3.2 & 716 & 5.2 & $S_{26}(29)+S_{22}(29)+S_{24}(29)$ \\
\hline$\delta$ ring 2 & $A^{\prime \prime}$ & 588 & 1.8 & 3.8 & 602 & 3.9 & $\mathrm{~S}_{18}(51)+\mathrm{S}_{19}(41)$ \\
\hline$\delta(\mathrm{C}=\mathrm{C}-\mathrm{O})$ & $A^{\prime}$ & 534 & 8.5 & 3.8 & 549,546 & $4.8,1.0$ & $S_{19}(74)+S_{18}(22)$ \\
\hline$\gamma(\mathrm{C}=\mathrm{O})$ & $A^{\prime \prime}$ & 485 & 12.5 & 0.6 & 495 & 8.9 & $S_{20}(43)+S_{21}(23)+S_{26}$ \\
\hline$\delta(\mathrm{C}=\mathrm{O})$ & $A^{\prime}$ & 442 & 1.8 & 1.1 & 460,455 & $1.5,1.9$ & $\mathrm{~S}_{13}(40)+\mathrm{S}_{18}(32)+\mathrm{S}_{19}(16)$ \\
\hline$\gamma$ ring 3 & $A^{\prime \prime}$ & 339 & 3.5 & 3.5 & Not studied & & $\mathrm{S}_{27}(70)$ \\
\hline$\gamma$ ring 1 & $A^{\prime \prime}$ & 145 & 1.2 & 1.2 & Not studied & & $S_{25}(72)+S_{27}(23)$ \\
\hline
\end{tabular}

${ }^{a}$ See Table 2 for symmetry coordinates definition; only PED contributions larger than $10 \%$ are presented.

which has a predominant contribution from the outof-plane movement of the $\mathrm{O}-\mathrm{C}=\mathrm{O}$ fragment.

In the Raman spectrum of $\alpha$-pyrone (pure liquid; Fig. 5), the most intense bands correspond to the $\nu \mathrm{C}=\mathrm{O}$ (split due to Fermi resonance) and $\nu \mathrm{C} 3=\mathrm{C} 4$ stretching modes and the $\delta \mathrm{C} 3-\mathrm{H}$ bending vibration (the band observed at $799 \mathrm{~cm}^{-1}$ is also relatively intense, but it has a contribution of both $\nu \mathrm{C} 2-\mathrm{C} 3$ stretching and $\gamma \mathrm{C} 6-\mathrm{H}$ rocking modes). These results are in agreement with the predicted Raman activities for the monomeric species, as shown in Table 4, and give further support to the idea of existence of relatively unimportant effects on the electron distribution in $\alpha$-pyrone due to intermolecular interactions in the condensed phase. The observed $\nu \mathrm{C}-\mathrm{H}$ stretching intensities are much smaller than as theoretically predicted, a result that can be attributed, at least partially, to a less good theoretical description of the polarizability properties of the hydrogen atoms.

The assignment of the less intense fundamentals in the various spectra under analysis could also be made without any particular difficulty, since the calculated spectrum fits the experimental data very well both with respect to frequencies and relative intensities (the proposed assignment of overtones and combination modes shall be considered as tentative). In addition, the observed fundamental frequencies in the pure liquid were found to be very similar to those of the isolated monomer. As it could be anticipated, the largest shift occurs for the $\nu \mathrm{C}=\mathrm{O}$ stretching $\left(-31 \mathrm{~cm}^{-1}\right)$, since, as already mentioned, intermolecular interactions involve predominantly the carbonyl bond. However, the changes in the carbonyl moiety induce other less pronounced structural changes that can also be noticed in the vibrational data. In fact, besides the observed shifts in $\nu \mathrm{C} 2-\mathrm{O}$ and $\nu \mathrm{C} 6-\mathrm{O}$, above discussed, the observed shifts in $\nu \mathrm{C} 3=\mathrm{C} 4$ $\left(-9 \mathrm{~cm}^{-1}\right), \quad \nu \mathrm{C} 5=\mathrm{C} 6 \quad\left(-11 \mathrm{~cm}^{-1}\right)$ and $\nu \mathrm{C} 2-\mathrm{C} 3$ $\left(+17 \mathrm{~cm}^{-1}\right)$ can also be explained in terms of secondary adjustments of the electron density in the pyrone ring due to the increase of polarization of the carbonyl bond resulting from the intermolecular interactions in the liquid, and indicate that the $\pi$ electron delocalization in the ring slightly increases in the condensed phase.

\section{2. $\gamma$-Pyrone}

The general agreement between the calculated spectra and the experimental data obtained for $\gamma$ pyrone is as good as for $\alpha$-pyrone. This enabled us to make a detailed assignment of the spectra of both the isolated monomer and room temperature crystalline phase (Fig. 6) with relative ease (see Tables 5 and 7). As for $\alpha$-pyrone, in $\gamma$-pyrone, the $\nu \mathrm{C}=\mathrm{O}$ stretching mode is predicted to give rise to the most intense infrared band. In the spectra of the isolated monomer, a triplet of bands are ascribed to this mode, resulting both from a Fermi interaction involving $\nu \mathrm{C}=\mathrm{O}$ and the first overtone of the $\left.\gamma \mathrm{C}_{\alpha}-\mathrm{H}\right)_{\mathrm{s}}$ rocking mode and matrix site splitting. In the spectrum of the crystal, the Fermi doublet appears at 1677 and $1659 \mathrm{~cm}^{-1}$, i.e. it exhibits a shift to lower frequencies of ca. $-20 \mathrm{~cm}^{-1}$ relatively to the gravity center of the set of bands observed in the matrix spectrum (see also Table 7). In consonance with the theoretical predictions, other 
Table 5

Calculated and observed vibrational frequencies, intensities and potential energy distributions (PED) for $\gamma$-pyrone monomer (frequencies in $\mathrm{cm}^{-1} . \nu$, stretching, $\delta$, in-plane bending; $\gamma$, out-of-plane bending, $\tau$, torsion; s, symmetric; as, asymmetric; N.o., not observed, FR, Fermi Resonance; the subscripts $\alpha$ and $\beta$ identify the carbon atoms in the $\alpha$ and $\beta$ positions in relation to the carbonyl group (see also Fig. 1); calculated infrared intensities $\left(I^{\mathrm{ir}}\right)$ in $\mathrm{km} \mathrm{mol}^{-1}$; calculated Raman activities $\left(I^{\mathrm{R}}\right)$ in $\AA^{4}$ Dalton ${ }^{-1}$; experimental intensities are peak intensities, normalized to the most intense band (only those bands with intensity larger than 0.5 are reported); assignment of overtones and combination bands should be considered as tentative)

\begin{tabular}{|c|c|c|c|c|c|c|c|}
\hline \multirow[t]{2}{*}{ Approximate description } & \multirow[t]{2}{*}{ Symmetry } & \multicolumn{3}{|c|}{ Calculated (HF/6-31G*) } & \multicolumn{2}{|c|}{$\begin{array}{l}\text { Observed (infrared; Ar matrix; } \\
T=8 \mathrm{~K} \text { ) }\end{array}$} & \multirow[t]{2}{*}{$\mathrm{PED}^{\mathrm{a}}$} \\
\hline & & $\nu$ & $\mathrm{I}^{\mathrm{ir}}$ & $I^{R}$ & $\nu$ & I & \\
\hline $2 \times \nu(\mathrm{C}=\mathrm{C})_{\mathrm{s}}$ & $A_{1}$ & & & & 3307,3294 & $1.5,1.2$ & \\
\hline$\nu(\mathrm{C}=\mathrm{C})_{\mathrm{as}}+\nu(\mathrm{C}=\mathrm{C})_{\mathrm{s}}$ & $B_{2}$ & & & & 3258 & 2.5 & \\
\hline $2 \times \nu(\mathrm{C}=\mathrm{C})_{\mathrm{as}}$ & $A_{1}$ & & & & 3140 & & \\
\hline$\nu\left(\mathrm{C}_{\beta}-\mathrm{H}\right)_{\mathrm{s}}$ & $A_{1}$ & 3067 & 3.8 & 194.6 & 3099 & & $S_{5}(88)+S_{4}(12)$ \\
\hline$\nu\left(\mathrm{C}_{\beta}-\mathrm{H}\right)_{\mathrm{as}}$ & $B_{2}$ & 3064 & 13.3 & 40.2 & 3082,3068 & & $S_{15}(87)+S_{14}(13)$ \\
\hline$\nu\left(\mathrm{C}_{\alpha}-\mathrm{H}\right)_{\mathrm{s}}$ & $A_{1}$ & 3038 & 0.6 & 53.7 & 3041 & & $S_{4}(88)+S_{5}(12)$ \\
\hline$\nu\left(\mathrm{C}_{\alpha}-\mathrm{H}\right)_{\mathrm{as}}$ & $B_{2}$ & 3037 & $<0.1$ & 82.9 & 3028,3018 & & $S_{14}(87)+S_{15}(13)$ \\
\hline$\delta\left(\mathrm{C}_{\beta}-\mathrm{H}\right)_{\mathrm{s}}+\nu(\mathrm{C}=\mathrm{C})_{\mathrm{s}}$ & $A_{1}$ & & & & 2970 & & \\
\hline$\nu(\mathrm{C}-\mathrm{O})_{\mathrm{as}}+\nu(\mathrm{C}-\mathrm{O})_{\mathrm{s}}$ & $B_{2}$ & & & & 2944 & & \\
\hline$\nu(\mathrm{C}-\mathrm{O})_{\mathrm{as}}+\nu(\mathrm{C}-\mathrm{C})_{\mathrm{s}}$ & $B_{2}$ & & & & 1791,1788 & $0.5,0.5$ & \\
\hline $2 \times \nu(\mathrm{C}-\mathrm{O})_{\mathrm{s}}$ & $A_{1}$ & & & & 1779 & 5.2 & \\
\hline$\nu(\mathrm{C}-\mathrm{O})_{\mathrm{s}}+\gamma\left(\mathrm{C}_{\alpha}-\mathrm{H}\right)_{\mathrm{s}}$ & $B_{1}$ & & & & 1767,1765 & $1.8,1.3$ & \\
\hline$\delta\left(\mathrm{C}_{\beta}-\mathrm{H}\right)_{\mathrm{as}}+\gamma \operatorname{ring} 1$ & $B_{1}$ & & & & 1728 & 4.2 & \\
\hline $2 \times \gamma\left(\mathrm{C}_{\alpha}-\mathrm{H}\right)_{\mathrm{s}}$ & $A_{1}$ & & & & 1703 & 2.6 & \\
\hline$\nu(\mathrm{C}=\mathrm{O}) \mathrm{FR}$ with & $A_{1}$ & 1757 & 636.2 & 68.6 & $1694,1685,1679$ & $68.2,100.0,26.2$ & $S_{6}(86)+S_{3}(14)$ \\
\hline $2 \gamma\left(\mathrm{C}_{\alpha}-\mathrm{H}\right)_{\mathrm{s}}$ & & & & & & & \\
\hline$\nu(\mathrm{C}=\mathrm{C})_{\mathrm{s}}$ & $A_{1}$ & 1656 & 74.7 & 23.0 & 1665,1656 & $15.7,21.8$ & $S_{2}(70)+S_{8}(17)+S_{1}(12)$ \\
\hline$\nu(\mathrm{C}=\mathrm{C})_{\mathrm{as}}$ & $B_{2}$ & 1589 & 6.0 & 4.9 & 1600,1593 & $5.6,14.3$ & $S_{12}(87)+S_{17}(10)$ \\
\hline $\begin{array}{l}\nu(\mathrm{C}-\mathrm{C})_{\mathrm{as}} \text { FR with } \\
\nu(\mathrm{C}-\mathrm{C})_{\mathrm{s}}+\delta \text { ring } 3\end{array}$ & $B_{2}$ & 1399 & 142.8 & 1.5 & $1448,1403,1398$ & $9.3,32.3,4.9$ & $\begin{array}{l}S_{13}(36)+S_{17}(32)+S_{11} \\
(16)+S_{16}(12)\end{array}$ \\
\hline$\delta\left(\mathrm{C}_{\beta}-\mathrm{H}\right)_{\mathrm{s}}$ & $A_{1}$ & 1390 & 1.1 & 4.1 & 1420,1415 & $3.7,4.1$ & $\mathrm{~S}_{8}(54)+\mathrm{S}_{9}(30)$ \\
\hline$\delta\left(\mathrm{C}_{\beta}-\mathrm{H}\right)_{\mathrm{as}}$ & $B_{2}$ & 1304 & 144.3 & 0.4 & 1318,1314 & $11.0,64.0$ & $S_{16}(44)+S_{11}$ \\
\hline$\delta\left(\mathrm{C}_{\alpha}-\mathrm{H}\right)_{\mathrm{as}}$ & $B_{2}$ & 1193 & $<0.1$ & 0.1 & 1224,1214 & $2.5,1.7$ & $S_{17}(55)+S_{13}(22)+S_{11}$ \\
\hline$\delta\left(\mathrm{C}_{\alpha}-\mathrm{H}\right)_{\mathrm{s}}$ & $A_{1}$ & 1178 & 19.8 & 15.1 & 1197,1194 & $2.8,13.5$ & $S_{9}(38)+S_{8}(28)+S_{2}(10)$ \\
\hline$\nu(\mathrm{C}-\mathrm{O})_{\mathrm{as}}$ & $B_{2}$ & 1013 & 13.7 & 3.0 & 1022 & 7.6 & $\begin{array}{l}S_{11}(48)+S_{17}(21)+S_{16} \\
(19)+S_{13}(16)\end{array}$ \\
\hline$\delta$ ring 1 & $A_{1}$ & 988 & 3.5 & 11.1 & 1005 & 2.5 & $S_{7}(15)+S_{9}(20)+S_{1}(16)$ \\
\hline$\gamma\left(\mathrm{C}_{\beta}-\mathrm{H}\right)_{\mathrm{as}}$ & $A_{2}$ & 987 & 0.0 & 0.9 & N.o. & & $S_{21}(84)$ \\
\hline$\gamma\left(\mathrm{C}_{\beta}-\mathrm{H}\right)_{\mathrm{s}}$ & $B_{1}$ & 981 & $<0.1$ & 2.1 & 986 & 1.6 & $\mathrm{~S}_{25}(91)$ \\
\hline$\nu(\mathrm{C}-\mathrm{O})_{\mathrm{s}}$ & $A_{1}$ & 907 & 117.5 & 5.1 & 922 & 61.7 & $S_{1}(73)+S_{10}(15)$ \\
\hline$\gamma\left(\mathrm{C}_{\alpha}-\mathrm{H}\right)_{\mathrm{s}}$ & $B_{1}$ & 850 & 106.4 & 1.8 & 856,847 & $6.2,38.2$ & $\mathrm{~S}_{24}(80)+\mathrm{S}_{25}(20)$ \\
\hline$\gamma\left(\mathrm{C}_{\alpha}-\mathrm{H}\right)_{\mathrm{as}}$ & $A_{2}$ & 808 & 0.0 & 8.2 & N.o. & & $\mathrm{S}_{20}(79)$ \\
\hline$\nu(\mathrm{C}-\mathrm{C})_{\mathrm{s}}$ & $A_{1}$ & 769 & 0.4 & 9.9 & 767,765 & $15.6,8.0$ & $\mathrm{~S}_{3}(85)$ \\
\hline$\gamma(\mathrm{C}=\mathrm{O})$ & $B_{1}$ & 721 & 2.0 & 7.1 & 724,721 & $1.0,1.1$ & $S_{23}(42)+S_{26}(44)$ \\
\hline$\delta$ ring 3 & $B_{2}$ & 621 & $<0.1$ & 3.8 & 638,636 & $1.6,1.3$ & $S_{19}(82)+S_{13}(18)$ \\
\hline$\delta$ ring 2 & $A_{1}$ & 479 & 0.4 & 2.3 & 474 & 1.3 & $\mathrm{~S}_{10}(96)$ \\
\hline$\delta(\mathrm{C}=\mathrm{O})$ & $B_{2}$ & 442 & 15.3 & 0.2 & 453 & 4.5 & $S_{18}(80)+S_{19}(11)$ \\
\hline$\gamma$ ring 2 & $B_{1}$ & 418 & 17.2 & 2.5 & 430 & 6.7 & $S_{26}(69)+S_{24}(20)$ \\
\hline$\gamma$ ring 1 & $A_{2}$ & 393 & 0.0 & 0.0 & N.o. & & $S_{22}(75)+S_{20}(22)$ \\
\hline$\gamma$ ring 3 & $B_{1}$ & 152 & 10.2 & 0.5 & Not studied & & $S_{27}(57)+S_{26}(25)$ \\
\hline
\end{tabular}

${ }^{\text {a }}$ See Table 3 for symmetry coordinates definition; only PED contributions larger than $10 \%$ are presented. 
Table 6

Observed infrared and Raman vibrational fundamental frequencies and intensities for $\alpha$-pyrone (pure liquid; room temperature) (frequencies in $\mathrm{cm}^{-1} . \nu$, stretching, $\delta$, in-plane bending; $\gamma$, out-of-plane bending, $\tau$, torsion; FR, Fermi Resonance; see Fig. 1 for atom numbering; experimental intensities are peak intensities, normalized to the most intense band)

\begin{tabular}{|c|c|c|c|c|c|c|}
\hline \multirow[t]{2}{*}{ Approximate description } & \multirow[t]{2}{*}{ Symmetry } & \multicolumn{3}{|l|}{ Infrared } & \multicolumn{2}{|l|}{ Raman } \\
\hline & & $\nu$ & I & $\Delta \nu^{\mathrm{a}}$ & $\nu$ & I \\
\hline$\nu(\mathrm{C} 6-\mathrm{H})$ & $A^{\prime}$ & 3105 & 18.2 & -3 & 3120 & 17.0 \\
\hline$\nu(\mathrm{C} 3-\mathrm{H})$ & $A^{\prime}$ & 3082 & 12.8 & -1 & 3094 & 8.9 \\
\hline$\nu(\mathrm{C} 5-\mathrm{H})$ & $A^{\prime}$ & 3057 & 9.6 & 0 & 3066 & 8.4 \\
\hline$\nu(\mathrm{C} 4-\mathrm{H})$ & $A^{\prime}$ & 3030 & 9.5 & -6 & 3044 & 4.3 \\
\hline$\nu(\mathrm{C}=\mathrm{O}) \mathrm{FR}$ with & $A^{\prime}$ & 1783,1742 & $8.3,100.0$ & -31 & 1748,1724 & $18.9,25.0$ \\
\hline$(\gamma \mathrm{C} 6-\mathrm{H}+\gamma \mathrm{C} 5-\mathrm{H})$ & & 1722 & 58.4 & & & \\
\hline$\nu(\mathrm{C} 5=\mathrm{C} 6)$ & $A^{\prime}$ & 1640,1624 & $8.3,20.2$ & -11 & 1637 & 11.2 \\
\hline$\nu(\mathrm{C} 3=\mathrm{C} 4)$ & $A^{\prime}$ & 1579,1543 & $5.0,28.6$ & -9 & 1553 & 100.0 \\
\hline$\delta(\mathrm{C} 6-\mathrm{H})$ & $A^{\prime}$ & 1428 & 6.0 & -2 & 1440 & 13.3 \\
\hline$\delta(\mathrm{C} 4-\mathrm{H})$ & $A^{\prime}$ & 1371 & 3.2 & -1 & 1384 & 10.5 \\
\hline$\nu(\mathrm{C} 6-\mathrm{O})$ & $A^{\prime}$ & 1246 & 23.5 & -6 & 1257 & 9.5 \\
\hline$\delta(\mathrm{C} 3-\mathrm{H})$ & $A^{\prime}$ & 1180 & 2.3 & 1 & 1191 & 60.0 \\
\hline$\nu(\mathrm{C} 2-\mathrm{O})$ & $A^{\prime}$ & 1122 & 18.4 & 7 & 1134 & 12.7 \\
\hline$\delta(\mathrm{C} 5-\mathrm{H})$ & $A^{\prime}$ & 1084,1068 & $16.6,17.1$ & -8 & 1095,1080 & $14.5,12.0$ \\
\hline$\gamma(\mathrm{C} 4-\mathrm{H})$ & $A^{\prime \prime}$ & 1045 & 1.2 & -18 & N.o. & \\
\hline$\gamma(\mathrm{C} 6-\mathrm{H})$ & $A^{\prime \prime}$ & 1002 & 1.2 & 9 & N.o. & \\
\hline$\nu(\mathrm{C} 4-\mathrm{C} 5)$ & $A^{\prime}$ & 975 & 4.4 & 1 & 987 & 13.8 \\
\hline$\delta$ ring 1 & $A^{\prime}$ & 946 & 9.5 & -2 & N.o. & \\
\hline$\gamma(\mathrm{C} 3-\mathrm{H})$ & $A^{\prime \prime}$ & 845 & 5.4 & 9 & 854 & 5.3 \\
\hline$\gamma(\mathrm{C} 5-\mathrm{H})$ & $A^{\prime \prime}$ & 782 & & 11 & 799 & \\
\hline$\nu(\mathrm{C} 2-\mathrm{C} 3)$ & $A^{\prime}$ & 782 & 28.7 & 17 & 799 & 42.6 \\
\hline$\gamma$ ring 2 & $A^{\prime \prime}$ & 724 & 3.3 & 8 & 727 & 4.3 \\
\hline$\delta$ ring 2 & $A^{\prime \prime}$ & 606 & 5.0 & 4 & 616 & 14.0 \\
\hline$\delta(\mathrm{C}=\mathrm{C}-\mathrm{O})$ & $A^{\prime}$ & 554 & 7.9 & 6 & 565 & 15.0 \\
\hline$\gamma(\mathrm{C}=\mathrm{O})$ & $A^{\prime \prime}$ & 498 & 9.6 & 3 & 513 & 4.6 \\
\hline$\delta(\mathrm{C}=\mathrm{O})$ & $A^{\prime}$ & 457 & 1.2 & 0 & 470 & 16.5 \\
\hline$\gamma$ ring 3 & $A^{\prime \prime}$ & Not studied & & - & 365 & 7.9 \\
\hline$\gamma$ ring 1 & $A^{\prime \prime}$ & Not studied & & - & 182 & 6.2 \\
\hline
\end{tabular}

${ }^{a}$ Band shift relative to the corresponding observed frequency for the monomer; when more than one band is ascribable to the same vibration the frequencies used to calculate $\Delta \nu$ correspond to the frequencies of the gravity centres of the observed bands, $\nu_{\mathrm{gc}}=\sum \nu_{i} I_{i} / \sum I_{i}$, where $\nu_{i}$ and $I_{i}$ are the frequencies and intensities of the component bands.

intense bands in the infrared spectra were easily assigned to $\nu(\mathrm{C}=\mathrm{C})_{\mathrm{s}}, \nu(\mathrm{C}-\mathrm{C})_{\mathrm{as}}, \delta\left(\mathrm{C}_{\beta}-\mathrm{H}\right)_{\mathrm{as}}, \nu(\mathrm{C}-\mathrm{O})_{\mathrm{s}}$ and $\gamma\left(\mathrm{C}_{\alpha}-\mathrm{H}\right)_{\mathrm{s}}$. As for $\alpha$-pyrone, the observed fundamental frequencies in the spectrum of crystalline $\gamma$-pyrone were found to be very similar to those of the isolated monomer, also pointing to relatively unimportant effects of intermolecular interactions on the vibrational properties of this molecule.

The observed $\nu \mathrm{C}-\mathrm{O}$ (asymmetric and symmetric) and $\nu \mathrm{C}=\mathrm{O}$ in the matrix-isolated $\gamma$-pyrone are observed at 1022, 922 and 1694/1685/1679 $\mathrm{cm}^{-1}$, respectively. The carbonyl stretching vibration is then shifted to lower frequencies by ca. 80-
$100 \mathrm{~cm}^{-1}$ when compared with the same vibration in $\alpha$-pyrone (multiplet in between 1755 and $1788 \mathrm{~cm}^{-1}$ — see Table 4). This result clearly reveals that the $\mathrm{C}=\mathrm{O}$ bond in $\gamma$-pyrone is stronger than in $\alpha$-pyrone, and correlates well with the relative $\mathrm{C}=\mathrm{O}$ bond lengths in the two molecules (120.0 and $118.4 \mathrm{pm}$, respectively; $\mathrm{HF} / 6-31 \mathrm{G}^{*}$ calculated values - see Table 1 ). The $\nu \mathrm{C}-\mathrm{O}$ modes are also shifted to lower frequencies in $\gamma$-pyrone when compared with the equivalent vibrations in $\alpha$ pyrone ( $\nu \mathrm{C} 6-\mathrm{O}: 1252 / 1245 \mathrm{~cm}^{-1}$; $\nu \mathrm{C} 2-\mathrm{O}: 1119$ / $\left.1114 \mathrm{~cm}^{-1}\right)$. This result is apparently surprising, since it is expected in the latter molecule that the 
Table 7

Observed infrared and Raman [6] vibrational fundamental frequencies and intensities for $\gamma$-pyrone (crystalline phase; room temperature) (frequencies in $\mathrm{cm}^{-1} . \nu$, stretching, $\delta$, in-plane bending; $\gamma$, out-of-plane bending, $\tau$, torsion; s, symmetric; as, asymmetric; FR, Fermi Resonance; N.o., not observed; see Fig. 1 for atom numbering; experimental intensities are peak intensities, normalized to the most intense band)

\begin{tabular}{|c|c|c|c|c|c|}
\hline \multirow[t]{2}{*}{ Approximate description } & \multirow[t]{2}{*}{ Symmetry } & \multicolumn{3}{|l|}{ Infrared } & \multirow{2}{*}{$\begin{array}{l}\text { Raman [6] } \\
\nu\end{array}$} \\
\hline & & $\nu$ & I & $\Delta \nu^{\mathrm{b}}$ & \\
\hline$\nu\left(\mathrm{C}_{\beta}-\mathrm{H}\right)_{\mathrm{s}}$ & $A_{1}$ & 3092 & 5.6 & -7 & 3130 \\
\hline$\nu\left(\mathrm{C}_{\beta}-\mathrm{H}\right)_{\mathrm{as}}$ & $B_{2}$ & 3068 & 12.6 & -7 & 3095 \\
\hline$\nu\left(\mathrm{C}_{\alpha}-\mathrm{H}\right)_{\mathrm{s}}$ & $A_{1}$ & 3045 & 5.8 & 4 & 3076 \\
\hline$\nu\left(\mathrm{C}_{\alpha}-\mathrm{H}\right)_{\mathrm{as}}$ & $B_{2}$ & 3021 & 5.4 & -2 & 3076 \\
\hline$\nu(\mathrm{C}=\mathrm{O}) \mathrm{FR}$ with $2 \gamma\left(\mathrm{C}_{\alpha}-\mathrm{H}\right)_{\mathrm{s}}$ & $A_{1}$ & 1677,1659 & $80.0,100.0$ & -20 & 1700,1672 \\
\hline$\nu(\mathrm{C}=\mathrm{C})_{\mathrm{s}}$ & $A_{1}$ & 1637 & 59.6 & -23 & 1658 \\
\hline$\nu(\mathrm{C}=\mathrm{C})_{\mathrm{as}}$ & $B_{2}$ & 1610 & 48.7 & 15 & 1610 \\
\hline$\nu(\mathrm{C}-\mathrm{C})_{\text {as }}$ FR with & $B_{2}$ & 1469,1462 & $6.7,6.0$ & 24 & 1415 \\
\hline$\nu(\mathrm{C}-\mathrm{C})_{\mathrm{s}}+\delta \operatorname{ring} 3$ & & 1417 & 20.9 & & \\
\hline$\delta\left(\mathrm{C}_{\beta}-\mathrm{H}\right)_{\mathrm{s}}$ & $A_{1}$ & 1399 & 6.0 & -18 & 1398 \\
\hline$\delta\left(\mathrm{C}_{\beta}-\mathrm{H}\right)_{\text {as }}$ & $B_{2}$ & 1319 & 55.9 & 4 & 1318 \\
\hline$\delta\left(\mathrm{C}_{\alpha}-\mathrm{H}\right)_{\mathrm{as}}$ & $B_{2}$ & 1216 & 7.1 & -4 & 1220 \\
\hline$\delta\left(\mathrm{C}_{\alpha}-\mathrm{H}\right)_{\mathrm{s}}$ & $A_{1}$ & 1203,1197 & $27.8,16.6$ & 6 & 1198 \\
\hline$\nu(\mathrm{C}-\mathrm{O})_{\mathrm{as}}$ & $B_{2}$ & 1029,1026 & $5.8,7.4$ & 5 & 1029 \\
\hline$\delta$ ring 1 & $A_{1}$ & 1010,1004 & $5.2,11.4$ & 1 & 1008 \\
\hline$\gamma\left(\mathrm{C}_{\beta}-\mathrm{H}\right)_{\mathrm{as}}$ & $A_{2}$ & N.o. & & - & N.o. \\
\hline$\gamma\left(\mathrm{C}_{\beta}-\mathrm{H}\right)_{\mathrm{s}}$ & $B_{1}$ & 969 & 2.7 & 17 & 960 \\
\hline$\nu(\mathrm{C}-\mathrm{O})_{\mathrm{s}}$ & $A_{1}$ & 922 & 7.3 & 0 & 924 \\
\hline$\gamma\left(\mathrm{C}_{\alpha}-\mathrm{H}\right)_{\mathrm{s}}$ & $B_{1}$ & 852 & 50.1 & 4 & 850 \\
\hline$\gamma\left(\mathrm{C}_{\alpha}-\mathrm{H}\right)_{\mathrm{as}}$ & $A_{2}$ & $(824)^{c}$ & 9.0 & - & 822 \\
\hline$\nu(\mathrm{C}-\mathrm{C})_{\mathrm{s}}$ & $A_{1}$ & N.o. & & - & 790 \\
\hline$\gamma(\mathrm{C}=\mathrm{O})$ & $B_{1}$ & 734 & 5.4 & 12 & 730 \\
\hline$\delta \operatorname{ring} 3$ & $B_{2}$ & 644 & 1.9 & 7 & 641 \\
\hline$\delta \operatorname{ring} 2$ & $A_{1}$ & 503 & 4.3 & 29 & 504 \\
\hline$\delta(\mathrm{C}=\mathrm{O})$ & $B_{2}$ & 456 & 28.3 & 3 & 453 \\
\hline$\gamma$ ring 2 & $B_{1}$ & Not studied & & - & 395 \\
\hline$\gamma$ ring 1 & $A_{2}$ & Not studied & & - & N.o. \\
\hline$\gamma$ ring 3 & $B_{1}$ & not studied & & - & 175 \\
\hline
\end{tabular}

${ }^{\text {a }}$ Raman intensities not reported in [6].

${ }^{\mathrm{b}}$ Band shift relative to the corresponding observed frequency for the monomer; when more than one band is ascribable to the same vibration the frequencies used to calculate $\Delta \nu$ correspond to the frequencies of the gravity centres of the observed bands, $\nu_{\mathrm{gc}}=\sum \nu_{i} I_{i} / \sum I_{i}$, where $\nu_{i}$ and $I_{i}$ are the frequencies and intensities of the component bands.

${ }^{c}$ In the monomer this vibration is symmetry forbidden in infrared.

electron density partially moves away from the C6$\mathrm{O} 1-\mathrm{C} 2$ fragment as a consequence of the repulsion between the closest oxygen lone electron pairs. However, the analysis of the potential energy distributions, shown in Tables 4 and 5, enabled us to explain the experimental findings. Indeed, in $\alpha$ pyrone, both $\nu \mathrm{C} 6-\mathrm{O}$ and $\nu \mathrm{C} 2-\mathrm{O}$ are extensively coupled with $\delta \mathrm{C}-\mathrm{H}$ bending coordinates, while in $\gamma$-pyrone the $\nu \mathrm{C}-\mathrm{O}$ modes are more localized vibrations; the different vibrational coupling can then justify the observed relative frequency values of the $\nu \mathrm{C}-\mathrm{O}$ modes in the two molecules.

As found for $\alpha$-pyrone, the spectroscopic data obtained for $\gamma$-pyrone also reveals that in the crystalline phase, the $\pi$ electron delocalization in the ring slightly increases due to the increase in polarization of the carbonyl bond resulting from intermolecular interactions. So, $\nu \mathrm{C}=\mathrm{O}$ decreases upon going from the isolated molecule to the crystal $[\Delta(\nu \mathrm{C}=\mathrm{O})=$ $\left.-20 \mathrm{~cm}^{-1}\right]$, while the $\nu \mathrm{C}-\mathrm{C}$ vibrations increase by 


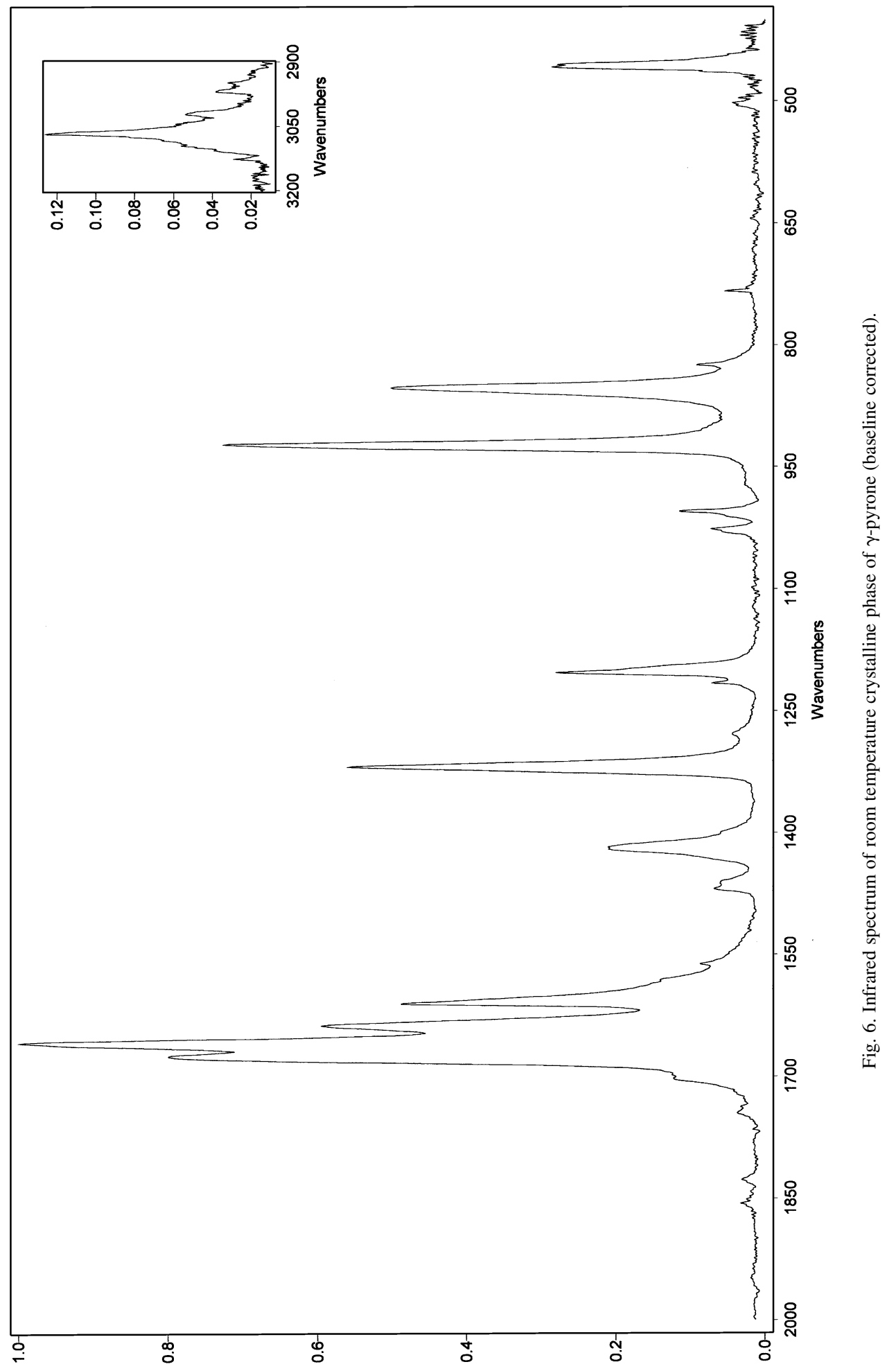


ca. $24 \mathrm{~cm}^{-1}$ and the $\nu \mathrm{C}=\mathrm{C}$ symmetric mode decreases by $-23 \mathrm{~cm}^{-1}$.

Finally, it is also interesting to compare the relative frequencies of the $\nu \mathrm{C}=\mathrm{C}$ and $\nu \mathrm{C}-\mathrm{C}$ stretching modes in the two molecules studied. $\nu \mathrm{C} 5=\mathrm{C} 6$ and $\nu \mathrm{C} 2-\mathrm{C} 3$ in $\alpha$-pyrone (observed in the argon matrix spectrum at 1646/1627 and 765 $\mathrm{cm}^{-1}$, respectively) were found to appear at nearly the same frequency of the $\nu \mathrm{C}=\mathrm{C}$ and $\nu \mathrm{C}-\mathrm{C}$ symmetric vibrations in $\gamma$-pyrone $(1665 / 1656$ and $\left.767 / 765 \mathrm{~cm}^{-1}\right)$. On the other hand, in $\alpha$-pyrone, $\nu \mathrm{C} 3=\mathrm{C} 4 \quad\left(1557 \mathrm{~cm}^{-1}\right)$ and $\nu \mathrm{C} 4-\mathrm{C} 5 \quad\left(974 \mathrm{~cm}^{-1}\right)$ are observed respectively at lower and higher frequencies than the above reference vibrations of $\gamma$-pyrone. These results correlate with a longer $\mathrm{C} 3=\mathrm{C} 4$ bond and a shorter $\mathrm{C} 4-\mathrm{C} 5$ bond in $\alpha$ pyrone (see Table 1) and indicate that in this molecule a $\pi$-system electron density migration occurs from the $\mathrm{C} 2-\mathrm{C} 3=\mathrm{C} 4$ fragment towards the $\mathrm{C} 4-\mathrm{C} 5=\mathrm{C} 6$ fragment, in order to partially compensate the electron deficiency in the $\sigma$ system of this latter moiety due to the strong electron attraction by the oxygen atoms.

\section{Conclusion}

The molecular structure and vibrational spectra of the monomeric forms of $\alpha$ - and $\gamma$-pyrone were for the first time investigated by combining ab initio MO calculations and matrix-isolation spectroscopy. A complete assignment of the vibrational spectra of these molecules could be made and the experimental data used to establish several correlations between the spectroscopic and structural properties of the studied compounds. Based on these correlations, further support was given to the idea that no extensive $\pi$-system delocalization occurs in both $\alpha$ and $\gamma$-pyrone moieties. In addition, comparison of the spectroscopic results obtained for the monomeric species with those obtained for the room temperature condensed phases reveal that intermolecular interactions in these phases do not affect the structure and vibrational properties of the studied molecules strongly. However, minor changes in the electron distribution within the pyrone rings due to intermolecular interactions in the condensed phases could be identified and shown to lead to an increased pyrone ring $\pi$-electron delocalization.

\section{Acknowledgements}

The authors would like to express their gratitude to Dr J. Seixas de Melo for his helpful criticism and Dr João Cecílio for technical help. This work has been held within the PRAXIS/QUI/10137/98 research project that is also partially funded by FEDER.

\section{References}

[1] R.S. Becker, S. Chakravorti, C. Gartner, M.G. Miguel, J. Chem. Soc. Faraday Trans. 89 (1993) 1007.

[2] A. Lopes, J. Seixas de Melo, A.J. Martins, A.L. Maçanita, F.S. Pina, H. Wamhoff, E.C. Melo, Environ. Sci. Technol. 29 (1995) 562.

[3] J. Seixas de Melo, Fotofísica Molecular de Cumarinas e Tiofenos. PhD Thesis, Department of Chemistry, New University of Lisbon, 1996.

[4] A.J. Blake, R.O. Gould, S.G. Harris, H. MacNab, S. Parsons, Acta. Crystallogr. C50 (1994) 1938.

[5] J.N. MacDonald, S.A. Mackay, J.K. Tyler, A.P. Cox, I.C. Ewart, J. Chem. Soc. Faraday Trans. II 77 (1981) 79.

[6] C. Thomson, C. Edge, Theochem. 121 (1985) 173.

[7] A. Somogyi, Z. Dinya, A. Császár, P. Császár, Theochem 133 (1985) 95.

[8] A. Somogyi, A. Császár, Z. Dinya, Acta. Chim. Hung. 124 (1987) 855.

[9] A. Somogyi, P. Császár, Z. Dinya, A. Császár, Theochem 151 (1987) 29.

[10] P. Császár, A. Császár, A. Somogyi, Z. Dinya, S. Holly, M. Gál, J.E. Boggs, Spectrochim. Acta A42 (1986) 473.

[11] J. Seixas de Melo, G. Quinteiro, J. Pina, S. Breda, R. Fausto, J. Mol. Struct. 59 (2001) 565-566.

[12] G. Quinteiro, Caracterização Espectroscópica de Pironas e Cumarinas. Department of Chemistry, University of Coimbra, Internal Report, 1998.

[13] W.J. Hehre, R. Ditchefield, J.A. Pople, J. Chem. Phys. 56 (1972) 2257.

[14] M.J. Frisch, G.W. Trucks, H.B. Schlegel, P.M.W. Gill, B.G. Jonhson, M.A. Robb, J.R. Cheeseman, T. Keith, G.A. Petersen, J.A. Montgomery, K. Raghavachari, M.A. AlLaham, V.G. Zakrzewski, J.V. Ortiz, J.B. Foresman, J. Cioslowski, B.B. Stefanov, A. Nanayakkara, M. Challacombe, C.Y. Peng, P.Y. Ayala, W. Chen, M.W. Wong, J.L. Andres, E.S. Replogle, R. Gomperts, R.L. Martin, D.J. Fox, J.S. Binkley, D.J. Defrees, J. Baker, J.P. Stewart, M. HeadGordon, C. Gonzalez, J.A. Pople. Gaussian 94 (Revision E.2). Gaussian Inc., Pittsburgh PA, 1994.

[15] C. Peng, P.Y. Ayala, H.B. Schlegel, M.J. Frisch, J. Comput. Chem. 17 (1996) 49.

[16] R. Fausto. TRANSFormer (version 2.0). Departamento de Química, Universidade de Coimbra, Portugal, 1996.

[17] M.D.G. Faria, R. Fausto. BUILD-G and VIBRAT (version 2.0). Departamento de Química, Universidade de Coimbra, Portugal, 1996. 
[18] J.E. Rice, B. Liu, T. Lee, C.M. Rohlfing, Chem. Phys. Lett. 161 (1989) 277.

[19] D.R. Lide, Tetrahedron 17 (1962) 125.

[20] L. Khriachtchev, J. Lundell, E. Isoniemi, M. Räsänen, J. Chem. Phys. 113 (2000) 4265.
[21] E.M.S. Maçôas, R. Fausto, J. Lundell, M. Pettersson, L. Khriachtchev, M. Räsänen, J. Phys. Chem. A 104 (2000) 11725 .

[22] S. Sander, H. Willner, L. Khriachtchev, M. Rasanen, E.L. Varetti, J. Mol. Spectrosc. 203 (2000) 145. 